\title{
Dark Fermentative Biohydrogen Production from Palm oil Mill Effluent: Operation Factors and Future Progress of Biohydrogen Energy
}

\author{
Fatin Sakinah Rosman ${ }^{1}$, Mohd Zulkhairi Mohd Yusoff ${ }^{1,2 *}$, Mohd Rafein Zakaria ${ }^{1,3}$, \\ Toshinari Maeda ${ }^{4}$ and Mohd Ali Hassan ${ }^{1}$ \\ ${ }^{1}$ Department of Bioprocess Technology, Faculty of Biotechnology and Biomolecular Sciences, Universiti Putra \\ Malaysia, 43400 Serdang, Selangor, Malaysia \\ ${ }^{2}$ Laboratory of Biopolymer and Derivatives, Institute of Tropical Forestry and Forest Products (INTROP), \\ Universiti Putra Malaysia, 43400 UPM Serdang, Selangor, Malaysia \\ ${ }^{3}$ Laboratory of Processing and Product Development, Institute of Plantation Studies, Universiti Putra Malaysia, \\ 43400, UPM Serdang, Selangor, Malaysia \\ ${ }^{4}$ Department of Biological Functions and Engineering, Graduate School of Life Science and Systems \\ Engineering, Kyushu Institute of Technology, 2-4 Hibikino, Wakamatsu-ku, \\ Kitakyushu, Fukuoka 808-0196, Japan
}

\begin{abstract}
ARTICLE INFO

Article history:

Received: 10 February 2020

Accepted: 13 November 2020

Published: 31 December 2020

DOI: https://doi.org/10.47836/pjst.28.S2.19

E-mail addresses:

sakinah_fatin@yahoo.com (Fatin Sakinah Rosman) mzulkhairi@upm.edu.my (Mohd Zulkhairi Mohd Yusoff)

mohdrafein@upm.edu.my (Mohd Rafein Zakaria)

toshi.maeda@life.kyutech.ac.jp (Toshinari Maeda)

alihas@upm.edu.my (Mohd Ali Hassan)

* Corresponding author
\end{abstract}

Malaysia is one of the largest producers and exporters of palm oil, thus, a large amount of palm oil mill effluent (POME) is generated through this process. POME contributes to environmental pollution if it is not properly treated. This complex effluent consists of colloidal matters and mainly organic components with more than $90 \%$ water. Thus, it is useful to be used as a substrate for fermentative processes, including biohydrogen production. Biohydrogen from POME is a renewable source that can potentially serve as an alternative to substitute fossil fuels. The abundance of POME and the rising price of fossil fuels in the global market create a demand for this source of energy. However, the complexity of the substituents in POME makes the optimisation of this effluent as a

substrate in dark fermentation a challenge. This review article explores the important parameters that need to be considered for optimal biohydrogen production, such as the bioreactor operational parameters and the microbial consortium. Besides, the potential of metabolic engineering as a tool to overcome the limitations of the microbial strains to metabolise POME for increased 
biohydrogen production was also reviewed. However, further research and development are needed to increase the biohydrogen yield on par with commercial demand.

Keywords: Biohydrogen, dark fermentation, hydrogen-producing microorganisms, palm oil mill effluent

\section{INTRODUCTION}

As the availability of fossil fuels is steadily decreasing over the years, a renewable alternative source of energy needs to be considered. Biohydrogen is one of the potential replacements of fossil fuels. Biohydrogen refers to hydrogen that has been generated through biological processes (Kapdan \& Kargi, 2006). Biohydrogen is a clean energy source and considered renewable since it can be produced continuously from various renewable sources such as oil palm biomass and food waste (Mohd Yasin et al., 2013). This gas is odourless, colourless, combustible, and nontoxic. Unlike hydrocarbon fuels, hydrogen gas burns cleanly without emitting any environmental pollutants. This is because hydrogen combustion only produces water vapour $\left(\mathrm{H}_{2} \mathrm{O}\right)$ (Mokhtar et al., 2019).

Table 1 shows the comparison between gasoline, ethanol, methane, and hydrogen, respectively as energy carriers. Biohydrogen is also an interesting biofuel since it is scaleindependent and has a high conversion rate to electricity via fuel cells compared to other gaseous fuels (Groot, 2003). According to the International Energy Agency (IEA), in 2018, the cost of hydrogen gas production from renewable sources is approximately USD 3.0$7.5 / \mathrm{kg}$, while the cost of using coal as a feedstock is about USD 1.2-2.2/ $\mathrm{kg}$ of hydrogen (IEA, 2020). In 2020, it can be seen that the prices of alternative fuels (biodiesel B20 USD 2.36/gallon, biodiesel B99-B100 USD 3.51/gallon) are comparative to hydrocarbon fuels (diesel USD 2.61/gallon and gasoline USD 1.91/gallon) (Energy, 2020).

In order to make the production of biohydrogen more sustainable and cost-effective, the use of renewable resources as the feedstock is more ideal compared to the conventional simple sugars. Thus, in conjunction with a sustainable and environmentally friendly strategy, many researchers have preferred to utilise organic biomass as alternative substrates for biohydrogen production.

The POME generated will be utilised by anaerobic microorganisms in a bioreactor as a substrate to generate biohydrogen through a process called dark fermentation. Thus, to take full advantage of this inexhaustible resource, the efficiency of the dark fermentation process by the microbes needs to be optimised. Therefore, this review also covers the crucial factors that may contribute to the efficiency of biohydrogen production through dark fermentation. This includes microbial limitation, environmental limitation, operational condition, and the application of metabolic engineered microorganisms. The current development and future projection of biohydrogen production from the renewable substrate were discussed thoroughly. 
Table 1

Properties of energy carriers; $\mathrm{H}_{2}, \mathrm{CH}_{4}$, ethanol, and gasoline

\begin{tabular}{lcccc}
\hline Energy Carrier Properties & Hydrogen & Methane & Ethanol & Gasoline \\
\hline Density, gas $(\mathrm{NTP})\left(\mathrm{kg} \mathrm{m}^{3-1}\right)$ & 0.0899 & 0.651 & N.A. & N.A. \\
Density, liquid $\left(\mathrm{kg} \mathrm{m}^{3-1}\right)$ & 70.8 & 422.6 & 789.3 & $720-780$ \\
Melting point $\left({ }^{\circ} \mathrm{C}\right)$ & -259.1 & -182.3 & -114.15 & -40 \\
Boiling point $\left({ }^{\circ} \mathrm{C}\right)$ & -252.76 & -161.15 & 78.29 & N.A. \\
Lower heating value $\left(\mathrm{MJ} \mathrm{kg}^{-1}\right)$ & 119.9 & 50.0 & N.A. & 44.6 \\
Energy per unit mass $\left(\mathrm{MJ} \mathrm{kg}^{-1}\right)^{*}$ & 141.9 & 55.5 & 29.9 & 47.4 \\
Energy per unit volume $\left(\mathrm{GJ} \mathrm{m}^{3-1}\right)$ & 0.013 & 0.651 & 23.6 & 34.85 \\
Flame temperature $\left({ }^{\circ} \mathrm{C}\right)$ & 2045 & 1875 & N.A. & 2200 \\
Self-ignition temperature $\left({ }^{\circ} \mathrm{C}\right)$ & 585 & 540 & 423 & $228-501$ \\
Minimal ignition energy $\left(\mathrm{mJ}^{3}\right)$ & 0.2 & 0.29 & N.A. & 0.24 \\
Ignition limits in air $(\mathrm{vol} \%)$ & $4-75$ & $5.3-15$ & $4.3-19$ & $1.0-7.6$ \\
Flame propagation in air $\left(\mathrm{m} \mathrm{s}^{-1}\right)$ & 2.65 & 0.4 & N.A. & 0.4 \\
Diffusion coefficient in air $\left(\mathrm{cm}^{2} \mathrm{~s}^{-1}\right)$ & 0.61 & 0.16 & N.A. & 0.05 \\
Toxicity & No & No & No & Yes \\
N.A. $=$ not available & & & & \\
\hline
\end{tabular}

Sources: (Najafpour et al., 2015: Xu et al., 2009)

\section{Substrate for Biohydrogen Production via Dark Fermentation}

The increasing trend in palm oil production gains the concern of environmental activist groups. This is because palm oil plantation expansion leads to deforestation, causing loss of biodiversity. An increase in palm oil production also reflected the increase in crude palm oil (CPO) production. CPO production becomes an environmental issue due to the massive generation of POME from the process of $\mathrm{CPO}$ extraction where a tonne of $\mathrm{CPO}$ produces approximately 3.05 tonnes of POME (Singh et al., 2010). POME is the largest wastewater produced and the most problematic environmental pollutant in the palm oil industry (Singh et al., 2010). This complex effluent is viscous, brownish in colour, and consists of colloidal matters, with more than $90 \%$ of water. The solids content of POME comprises more than 5\% total solids and around 4\% suspended solids (Taifor et al., 2017). The POME also has a discharge temperature of $80-90^{\circ} \mathrm{C}$.

The pre-treatment of POME is vital before its utilisation, not only as a substrate for biohydrogen production through microbial fermentation but also for the production of various products such as biosolvents (Hipolito et al., 2008), bioacids (Mumtaz et al., 2008) and polyhydroxyalkanoates (PHA) (Hassan et al., 1997). The alkaline-heat supernatant pretreatment was shown to produce the highest biohydrogen production $\left(2.18 \mathrm{~mol} \mathrm{H}_{2} / \mathrm{mol}\right.$ total carbohydrate) by POME compared to other pre-treatment like acid (Kamal et al., 2012). 


\section{MATERIALS AND METHODS}

\section{General Factors that Influence Biohydrogen Productivity: Nutrients}

Macronutrients and micronutrients are essential in dark fermentation which includes: carbon and nitrogen sources (Lin \& Lay, 2004a), ammonium, phosphate (Lin \& Lay, 2004b), sulphur, sulphate (Cheng et al., 2011), iron (Yang \& Shen, 2006), and elemental traces (Lin \& Lay, 2005). The concentration of these nutrients also influences the growth of microbes and hydrogen production. The ranges of nitrogen concentration around 0.1-2.0 $\mathrm{g} \mathrm{N} / \mathrm{L}$ with a $\mathrm{C} / \mathrm{N}$ ratio of 3.3 to 130 were found to result in optimal growth.

Besides microbial growth, the efficiency of biohydrogen production also relies on the microbial hydrogenases that are involved in hydrogen metabolism. The most important element that influences the action of hydrogenases is ferredoxin (Chou et al., 2007). This is because iron is important for hydrogenase activity and may deviate the fermentation pathways away from biohydrogen production (Yang \& Shen, 2006). Reported that magnesium, sodium, and zinc were reported as the most significant elements for biohydrogen production. The optimum concentrations of elements were $(\mathrm{mg} / \mathrm{L}) 0.25 \mathrm{Zn}^{2+}$, $4.8 \mathrm{Mg}^{2+}, 1 \mathrm{Fe}^{2+}$ and $393 \mathrm{Na}^{+}$. The maximum biohydrogen yield was $233 \mathrm{~mL} \mathrm{H}_{2} / \mathrm{g} /$ hexose from sucrose-containing wastewater (Lin \& Lay, 2005).

Buffer. Organic acids are by-products produced from the dark fermentation of biohydrogen production. The accumulation of these acids will reduce the $\mathrm{pH}$ of the growth medium of the microbes, resulting in a decrease in biohydrogen production or stunting the microbial growth. Therefore, a strong buffer in the medium is required to oppose the $\mathrm{pH}$ change caused by organic acids produced. Carbonate buffers $\left(\mathrm{NaHCO}_{3}\right.$ and $\left.\mathrm{NH}_{4} \mathrm{CO}_{3}\right)$ are widely used in biohydrogen dark fermentation studies. However, the use of these buffers may result in the formation of additional $\mathrm{CO}_{2}$ due to the interaction of $\mathrm{HCO}_{3}$-with acidic metabolites (Lin $\&$ Lay, 2005). This situation should be avoided as the gas build-up will induce toxicity of the microbial environment. Hence, the use of phosphate buffer is preferable to alleviate this concern. This is because some studies have found that the use of phosphate buffers like $\mathrm{K}_{2} \mathrm{HPO}_{4}$ and $\mathrm{Na}_{2} \mathrm{HPO}_{4}$ could maintain the $\mathrm{pH}$ values of the medium and promote hydrogen production (Lin et al., 2011).

Hydrogen Partial Pressure. The theory predicts that by reducing the partial pressure of hydrogen may increase the biohydrogen yields from glycerol. High dissolved $\mathrm{H}_{2}$ concentration in the culture medium inhibits $\mathrm{H}_{2}$ production and favour the hydrogen consumption pathway instead (Mandal et al., 2006). Immediate removal of $\mathrm{H}_{2}$ from the culture medium is recommended to facilitate maximum $\mathrm{H}_{2}$ yields that showed hydrogen yield was doubled to $3.9 \mathrm{~mol} \mathrm{H}_{2} / \mathrm{mol}$ glucose (Chong et al., 2009). Another method that can be employed is by adding chemicals like $\mathrm{KOH}$ and $\mathrm{NaOH}$, to absorb carbon dioxide 
from the headspace and by removing the dissolved gases (Saady, 2013). The addition of the chemicals will create a vacuum environment. However, the addition of the chemicals will increase the $\mathrm{pH}$ of the medium, thus, affecting the optimal $\mathrm{pH}$ needed to maintain bacterial growth. Agitation served to remove dissolved gases such as $\mathrm{CO}_{2}$ and $\mathrm{H}_{2}$ from the fermentation medium. Ferchichi et al. (2005) revealed the agitation up to $100 \mathrm{rev} / \mathrm{min}$ yielded $1.66 \mathrm{~mol}-\mathrm{H}_{2} / \mathrm{mol}$.

\section{Limitation of Dark Fermentation for Biohydrogen Production}

Physicochemical Conditions. Table 2 depicts the advantages, disadvantages, and mechanisms of biohydrogen production through dark fermentation. The metabolism of bacteria for biohydrogen production through dark fermentation is highly dependent on the physicochemical factors. Among the crucial factors are the $\mathrm{pH}$, hydraulic retention time, partial pressure of hydrogen, temperature, fermentation products, by-products inhabitation and growth media.

Table 2

Microbial biohydrogen production mechanisms by dark fermentation: advantages and disadvantages

\begin{tabular}{lll}
\hline Mechanism & $\mathrm{C}_{6} \mathrm{H}_{12} \mathrm{O}_{6}+2 \mathrm{H}_{2} \mathrm{O} \rightarrow 2 \mathrm{CH}_{3} \mathrm{COOH}+4 \mathrm{H}_{2}+2 \mathrm{CO}_{2}$ \\
\hline Advantages & - $\mathrm{H}_{2}$ production from various carbohydrates and organic wastes \\
& - $\mathrm{High} \mathrm{H}_{2}$ production rates \\
& - So light required \\
& - $\mathrm{H}_{2}$ can be produced along with the high-value compounds (e.g.: glucogenic acid \\
& and 1,3-propanediol) \\
Disadvantages & - $\mathrm{CO}_{2}$ present in the product gas \\
& - Incomplete oxidisation of organic materials to $\mathrm{H}_{2}$, low $\mathrm{H}_{2}$ yields \\
& - Impurity of product gas, traces of $\mathrm{H}_{2} \mathrm{~S}$, methane and carbon dioxide. \\
\hline
\end{tabular}

Sources: Mohd Yasin et al. 2011; Vignais \& Billoud 2007

Substrate Inhibition. The mechanisms of biohydrogen production involving microbes are catalysed by mainly hydrogenase and nitrogenase enzymes (Vignais et al., 2006). Both mechanisms utilise the presence of protons as the electron sink during the metabolism of organic substrates that act as electron donors. The nitrogenase enzyme catalyses the reduction of nitrogen gas to ammonia (Tamagnini et al., 2002). The absence of $\mathrm{N}_{2}$ will, therefore, shift the total electron flux to biohydrogen production instead. This reaction is irreversible and can produce biohydrogen even at saturated biohydrogen concentration in the medium and this reaction is energy-intensive (Vignais et al., 2006).

The hydrogenases can be distinguished based on the types of electron donors and acceptors used in hydrogen metabolisms such as NAD, cytochrome, coenzyme, and ferredoxins. The enzymes can also be classed based on the metallic cofactors and 
sequence similarity of the hydrogenases. There are currently three known classes: [NiFe]hydrogenases (Forzi \& Sawers, 2007), [FeFe]-hydrogenases and [Fe]-hydrogenases (Fang et al., 2017). Interestingly, it was found that the functionality of the different Hyd enzymes largely depending on the $\mathrm{pH}$ (Sanchez-Torres et al., 2013). The majority of studies on biohydrogen production involves the metabolism of simple sugars. POME is a complex substance which could not be readily available for microbes to metabolise. It leads to long adaptive phases and low conversion rates into the product. However, the components of the complex substrates will be transformed into simple compounds through the degradation process. The stoichiometric reactions involved in the dark fermentation were explicated in Table 3.

Table 3

Stoichiometries reaction of dark fermentation of glucose for biohydrogen production

\begin{tabular}{|c|c|c|c|}
\hline Reaction & Stoichiometry & $\begin{array}{c}\Delta \mathbf{G 0}, \\
\text { (kJ reaction) }\end{array}$ & Reference \\
\hline Oxidation of glucose & $\mathrm{C}_{6} \mathrm{H}_{12} \mathrm{O}_{6}+12 \mathrm{H}_{2} \mathrm{O} \rightarrow 12 \mathrm{H}_{2}+6 \mathrm{HCO}_{3}^{-}+6 \mathrm{H}^{+}$ & +3.2 & \multirow{4}{*}{$\begin{array}{l}\text { (Chou et al., } \\
\text { 2008) }\end{array}$} \\
\hline Acetate production & $\begin{array}{l}\mathrm{C}_{6} \mathrm{H}_{12} \mathrm{O}_{6}+4 \mathrm{H}_{2} \mathrm{O} \rightarrow 2 \mathrm{CH}_{3} \mathrm{COO}^{-}+4 \mathrm{H}_{2}+2 \mathrm{HCO}_{3}^{-} \\
+4 \mathrm{H}^{+}\end{array}$ & -206.3 & \\
\hline Butyrate production & $\begin{array}{l}\mathrm{C}_{6} \mathrm{H}_{12} \mathrm{O}_{6}+2 \mathrm{H}_{2} \mathrm{O} \rightarrow \mathrm{CH}_{3} \mathrm{CH}_{2} \mathrm{CH}_{2} \mathrm{COO}^{-}+2 \mathrm{H}_{2}+ \\
2 \mathrm{HCO}_{3}{ }^{-}+3 \mathrm{H}^{+}\end{array}$ & -254.8 & \\
\hline Ethanol production & $\begin{array}{l}\mathrm{C}_{6} \mathrm{H}_{12} \mathrm{O}_{6}+2 \mathrm{H}_{2} \mathrm{O} \rightarrow 2 \mathrm{CH}_{3} \mathrm{CH}_{2} \mathrm{OH}+2 \mathrm{HCO}_{3}^{-}+ \\
2 \mathrm{H}^{+}\end{array}$ & -235.0 & \\
\hline $\begin{array}{l}\text { Acetate and ethanol } \\
\text { Production }\end{array}$ & $\begin{array}{l}\mathrm{C}_{6} \mathrm{H}_{12} \mathrm{O}_{6}+3 \mathrm{H}_{2} \mathrm{O} \rightarrow \mathrm{CH}_{3} \mathrm{CH}_{2} \mathrm{OH}+\mathrm{CH}_{3} \mathrm{COO}^{-}+ \\
2 \mathrm{H}_{2}+2 \mathrm{HCO}_{3}^{-}+3 \mathrm{H}^{+}\end{array}$ & -215.716 & $\begin{array}{l}\text { (Hwang et al., } \\
\text { 2004) }\end{array}$ \\
\hline Lactate production & $\mathrm{C}_{6} \mathrm{H}_{12} \mathrm{O}_{6} \rightarrow 2 \mathrm{CH}_{3} \mathrm{CHOHCOO}^{-}+2 \mathrm{H}^{+}$ & -198.1 & $\begin{array}{l}\text { (Kim et al., } \\
\text { 2009) }\end{array}$ \\
\hline Butanol production & $\begin{array}{l}\mathrm{C}_{6} \mathrm{H}_{12} \mathrm{O}_{6}+\mathrm{H}_{2} \mathrm{O} \rightarrow \mathrm{CH}_{3} \mathrm{CH}_{2} \mathrm{CH}_{2} \mathrm{OH}+2 \mathrm{HCO}_{3}^{-}+ \\
2 \mathrm{H}^{+}\end{array}$ & -280.5 & $\begin{array}{l}\text { (Chin et al., } \\
\text { 2003) }\end{array}$ \\
\hline Propionate production & $\mathrm{C}_{6} \mathrm{H}_{12} \mathrm{O}_{6}+2 \mathrm{H}_{2} \rightarrow 2 \mathrm{CH}_{3} \mathrm{CH}_{2} \mathrm{COO}^{-}+2 \mathrm{H}_{2} \mathrm{O}+2 \mathrm{H}^{+}$ & -359.0 & $\begin{array}{l}\text { (Morimoto et } \\
\text { al., 2005) }\end{array}$ \\
\hline Valerate production & $\begin{array}{l}\mathrm{C}_{6} \mathrm{H}_{12} \mathrm{O}_{6}+\mathrm{H}_{2} \rightarrow \mathrm{CH}_{3} \mathrm{CH}_{2} \mathrm{CH}_{2} \mathrm{CH}_{2} \mathrm{COO}^{-}+\mathrm{HCO}_{3}^{-} \\
+\mathrm{H}_{2} \mathrm{O}+2 \mathrm{H}^{+}\end{array}$ & -330.9 & \multirow{2}{*}{$\begin{array}{l}\text { (Chou et al., } \\
\text { 2008) }\end{array}$} \\
\hline Acetogenesis & $4 \mathrm{H}_{2}+2 \mathrm{HCO}_{3}^{-}+\mathrm{H}^{+} \rightarrow \mathrm{CH}_{3} \mathrm{COO}^{-}+4 \mathrm{H}_{2} \mathrm{O}$ & -104.6 & \\
\hline Acidogenesis & $\mathrm{C}_{6} \mathrm{H}_{12} \mathrm{O}_{6} \rightarrow 3 \mathrm{CH}_{3} \mathrm{COO}^{-}+3 \mathrm{H}^{+}$ & -310.6 & $\begin{array}{l}\text { (Kim et al., } \\
\text { 2009) }\end{array}$ \\
\hline
\end{tabular}

Temperature. The temperature influences the microbial growth and consequently increases enzymatic reactions and the rate of chemical synthesis (Dasgupta et al., 2010). Dark fermentation metabolism can occur within a wide range of temperatures $15-45^{\circ} \mathrm{C}$ (mesophilic), hyper-thermophilic (more than $80^{\circ} \mathrm{C}$ ). Previous studies on the production of biohydrogen under thermophilic conditions were compared in Table 4.

The effects of temperature from mesophilic to thermophilic $\left(25-55^{\circ} \mathrm{C}\right)$ during the fermentation were investigated by Yossan et al. (2012) and the results showed that the 


\begin{tabular}{ll}
\hline \multicolumn{1}{c}{ Advantages } & \multicolumn{1}{c}{ Disadvantages } \\
\hline - Increase in the rates of chemical and enzymatic reactions & Low cell densities \\
- Increase in thermodynamic favourability of $\mathrm{H}_{2}$-production. $\mathrm{H}_{2}$ production & $\begin{array}{l}\text { achieved } \\
\text { becomes less affected by the partial pressure of } \mathrm{H}_{2} \text {. }\end{array}$ \\
- The solubility of $\mathrm{H}_{2}$ and $\mathrm{CO}_{2}$ to water decreases & heating need for \\
- Reactors are less prone to contamination by $\mathrm{H}_{2}$-consuming organisms & \\
- Decreased diversity of side products & \\
- Some thermophiles excrete exoenzymes, which can hydrolyze biopolymers & \\
- Suitable for direct processing high-temperature wastewaters & \\
- Destruction of pathogens in the reactor effluent &
\end{tabular}

Source: (Hallenbeck, 2005; Hawkes et al., 2002)

biohydrogen yield was optimum at $37^{\circ} \mathrm{C}$. The highest yield of biohydrogen was obtained using $55^{\circ} \mathrm{C}$ reactor temperature with $985.3 \mathrm{~mL} / \mathrm{L}$ POME. O-thong et al. (2011) optimised three different temperatures between $35-75^{\circ} \mathrm{C}$, which produced the biohydrogen production at $1104 \mathrm{~mL} \mathrm{H}_{2} / \mathrm{L} \mathrm{POME}\left(35^{\circ} \mathrm{C}\right)$, and maximum at $4750 \mathrm{~mL} \mathrm{H}_{2} / \mathrm{L} \mathrm{POME}\left(55^{\circ} \mathrm{C}\right)$, respectively. Based on the statistical analysis, the optimal condition for biohydrogen production was at $60^{\circ} \mathrm{C}$, with a maximum production of biohydrogen at $4820 \mathrm{~mL} \mathrm{H}_{2} / \mathrm{L}$ POME. These studies have clearly shown that high temperature is the most ideal fermentation temperature to achieve the highest biohydrogen yield using POME.

pH. The optimal growth $\mathrm{pH}$ is microbial dependent and an important factor in suppressing the behaviour of the hydrogen-consuming methanogens. Studies showed different initial $\mathrm{pH}$ yielded different biohydrogen value, $2584 \mathrm{~mL} \mathrm{H}_{2} / \mathrm{L} \mathrm{POME} \mathrm{(pH} \mathrm{4.5),} 4750 \mathrm{~mL} \mathrm{H}_{2} / \mathrm{L}$ POME (pH 5.5) and $4300 \mathrm{~mL} \mathrm{H}_{2} /$ L POME (pH 6.5), respectively (O-thong et al., 2011). The optimal initial $\mathrm{pH}$ for biohydrogen production was found at 5.5, where the reaction achieved the maximum production of biohydrogen at $4820 \mathrm{~mL} \mathrm{H}_{2} \mathrm{~L} / \mathrm{POME}$. RSM analyses from different studies showed the optimum production of biohydrogen was found at 272 $\mathrm{mL} \mathrm{H}_{2} / \mathrm{g}$ substrate with an initial $\mathrm{pH}$ around 5.70. Another experiment using microflora in POME sludge also showed that the maximum biohydrogen production rate was $98 \mathrm{~mL}$ $\mathrm{H}_{2} / \mathrm{h}$ with initial $\mathrm{pH}$ at 5.98 (Rasdi et al., 2009).

Under slightly acidic conditions, the bacteria growth of methanogens will be suppressed. The ability of biohydrogen-producing bacteria to develop will be increased. Moreover, controlling the $\mathrm{pH}$ in dark fermentation is important because organic acids generated as by-products tend to reduce the $\mathrm{pH}$ of the culture medium (Li \& Chen, 2007).

Products Inhibition. Biohydrogen is typically produced from the metabolism of glucose or sucrose that also produces secondary products such as acetate and butyrate. The organic 
acids can reduce the rate of cell growth at lower concentrations and cause changes in cell metabolic process (Kyazze et al., 2006). The organic acids (undissociated) may pass through the cell membrane and dissociate within the cell of bacteria. This occurs when the $\mathrm{pH}$ inside the cell is higher than its surroundings. Therefore, high organic acid concentrations can disrupt the proton motive force ( $\mathrm{pH}$ gradient) across the cell membrane, resulting in metabolic inhibition (Van Ginkel \& Logan, 2005). Thus, biohydrogen production is typically more influenced by the disassociated butyric acid than by acetic acid, due to butyric acid having lower $\mathrm{pK}_{\mathrm{a}}$ value than acetic acid at 4.7 (Hawkes et al., 2007).

Another end-product which could suppress the biohydrogen production is ethanol. Lack of bacteria tolerance against ethanol. Thermophilic bacteria are less ethanol-tolerant than mesophilic bacteria (Burdette et al., 2002). The most ethanol-tolerant strains are the Thermoanaerobacter sp. strain A10 (Georgieva et al., 2007) and Clostridium thermocellum sp. strain SS22 (5\% (v/v) (Rani \& Seenayya, 1999).

Inoculum. Most of the microbes that are studied for biohydrogen production are obligate anaerobes (i.e Clostridia). However, the combination of facultative anaerobes with obligate anaerobes in the biohydrogen production may create more advantageous (Chong et al., 2009). Several bacteria can metabolise the complex material such as POME into simple sugars or organic acids, while others utilise these intermediate products to produce biohydrogen. The highest yield of biohydrogen was reported to be at $2.15 \mathrm{~mol} \mathrm{H}_{2} / \mathrm{mol}$ hexose from 3.2 L anaerobic batch sequencing reactor (ASBR) (O-Thong et al., 2007). In another study, the highest biohydrogen yield was $1773 \mathrm{~N} \mathrm{~mL} \mathrm{H}_{2} / \mathrm{L}$ POME using continuous batch. The studies evidenced that mixed cultures are more advantageous compared to pure cultures.

Single culture also plays a significant role particularly its metabolism and the optimal growth conditions during biohydrogen production. O-Thong et al. (2009) showed that the Thermoanaerobacterium had produced $25.9 \mathrm{mmol}_{2} / \mathrm{d}$ from POME. Chong and colleagues found that the Clostridium butyricum EB6 generated $948 \mathrm{~mL} \mathrm{H} / \mathrm{mL}$ glucose from POME (Chong et al., 2009). Besides, it is also important to reduce the presence of bacteria that may inhibit the production of biohydrogen like methanogens and sulphate reducers. Methanogens may be depleted using shorter hydraulic retention time (HRT), provided that the HRT is not exceeding the crucial value where biohydrogen producing bacteria may be washed out (Ismail et al., 2010).

\section{Metabolic Engineering Approaches}

Metabolic engineering is one of the available strategies to address the limitations presented by dark fermentation in the production of biohydrogen. The theoretical biohydrogen yield from dark fermentation using glucose as a carbon source is $12 \mathrm{~mol} \mathrm{H}_{2}$ and 6 mol CO 2 per 
mole glucose, but there are no reported natural bacteria that possess the metabolism that is capable to generate this value (Chaudhary et al., 2012). However, based on several known fermentation reactions, the theoretical maximum $\mathrm{H}_{2}$ yield is only $4 \mathrm{~mol} \mathrm{H}_{2} / \mathrm{mol}_{\text {glucose }}$ produced by strictly anaerobic bacteria. Meanwhile, facultative bacteria can only produce biohydrogen yield of $2 \mathrm{~mol} \mathrm{H}_{2} / \mathrm{mol}$ glucose (Mohd Yasin et al., 2013). Therefore, the theoretical maximum yield represents only $25 \%$ of substrate conversion into biohydrogen, signalling the inefficiency of the system. This is because other metabolic by-products of dark fermentation like butyrate, propionate, ethanol, lactate, including biomass, are also generated in significant amounts (Table 3 ).

E.coli has been employed as a robust model strain for metabolic engineering and protein engineering to improve the productivity of hydrogen-producing bacteria (Sanchez-Torres et al., 2013). Even though obligate anaerobes like Clostridia spp. showed higher hydrogen production compared to E. coli (Table 5), they require more sophisticated cultivation set-up because they are obligate anaerobes.

Table 5

Types of microorganism, bioreactor types and scales and biohydrogen production from POME through the dark fermentation process

\begin{tabular}{|c|c|c|c|c|}
\hline Microorganism & Hydrogen Yield & $\begin{array}{c}\text { Hydrogen } \\
\text { Production Rate }\end{array}$ & Reactor Type & References \\
\hline C. butyricum EB6 & $\begin{array}{l}298 \mathrm{~mL} \mathrm{H}_{2} / \mathrm{g} \\
\text { carbohydrate }\end{array}$ & $849.5 \mathrm{~mL} \mathrm{H}_{2 /} \mathrm{h}$ & 3L Reactor & $\begin{array}{c}\text { (Chong, } \\
\text { Sabaratnam, et } \\
\text { al., 2009) }\end{array}$ \\
\hline Thermoanaerobacterium- & $6.5 \mathrm{~L} \mathrm{H}_{2} / \mathrm{L}-\mathrm{POME}$ & $25.9 \mathrm{mmol} \mathrm{H}_{2} / \mathrm{L} / \mathrm{d}$ & $150 \mathrm{~mL}$ bottle & $\begin{array}{c}\text { (O-Thong et al., } \\
\text { 2007) }\end{array}$ \\
\hline Thermosaccharolyticum & 4.6 L H $\mathrm{L}_{2} / \mathrm{L}-\mathrm{POME}$ & - & $1 \mathrm{~L}$ ASBR & \\
\hline Mixed culture & $\begin{array}{c}199 \mathrm{mmol} \mathrm{H}_{2} / \mathrm{L}- \\
\text { POME }\end{array}$ & - & 1L Reactor & $\begin{array}{c}\text { (O-Thong et al., } \\
\text { 2007) }\end{array}$ \\
\hline Mixed culture & $0.27 \mathrm{~L} \mathrm{H}_{2} / \mathrm{g}-\mathrm{COD}$ & $\begin{array}{c}9.1 \mathrm{~L} \mathrm{H}_{2} / \mathrm{L} / \\
\mathrm{POME} / \mathrm{d}\end{array}$ & 3.2L ASBR & $\begin{array}{c}\text { (Prasertsan et al., } \\
\text { 2009) }\end{array}$ \\
\hline Mixed culture & $\begin{array}{l}840 \mathrm{NmL} \mathrm{H}_{2} / \mathrm{L}- \\
\text { POME }\end{array}$ & $\begin{array}{c}35 \mathrm{~N} \mathrm{~mL} / \mathrm{H}_{2 /} \mathrm{L} / \\
\mathrm{POME} / \mathrm{h}\end{array}$ & 50L CSTR & $\begin{array}{l}\text { (Yusoff et al., } \\
\text { 2009) }\end{array}$ \\
\hline Suspended Mixed culture & $\begin{array}{c}145.9 \mathrm{~cm}^{3} \mathrm{H}_{2} / \mathrm{g}- \\
\mathrm{COD}\end{array}$ & $\begin{array}{c}240.5 \mathrm{~cm}^{3} \mathrm{H}_{2} / \mathrm{g}- \\
\mathrm{VSS} / \mathrm{d}\end{array}$ & $122 \mathrm{~cm}^{3}$ vials & $\begin{array}{l}\text { (Ismail et al., } \\
\text { 2010) }\end{array}$ \\
\hline Mixed culture & $\begin{array}{c}1054 \mathrm{NmL} \mathrm{H}_{2} / \mathrm{L}- \\
\mathrm{POME}\end{array}$ & $\begin{array}{c}44 \mathrm{~N} \mathrm{~mL} \mathrm{H}_{2} / \mathrm{L} / \\
\mathrm{POME} / \mathrm{h}\end{array}$ & 50L CSTR & $\begin{array}{l}\text { (Yusoff et al., } \\
\text { 2009) }\end{array}$ \\
\hline
\end{tabular}

Maeda and his colleagues designed the robust engineered E. coli strains for enhanced biohydrogen production (Maeda et al., 2008). To date, the framework for metabolic engineering is restricted to the well-described microorganism, limiting the window of opportunity to discover novel genes that may increase the production of biohydrogen. 


\section{Future Progress of Dark Fermentation for Biohydrogen Production}

The largest obstacle to biohydrogen production using POME was low biohydrogen molar yield, which only reached $10-20 \%$ of the total energy the substrate can provide (Angenent et al., 2004). In addition, estimation of the use of POME to produce biohydrogen is determined using simple sugars such as glucose, since it is impossible to measure the moles of complex substrates like POME. Many studies have shown that the lower yield of biohydrogen production through dark fermentation is due to the bioconversion of POME into multiple by-products (Hipolito et al., 2008). The presence of multiple by-products will not only increase the $\mathrm{pH}$ of the culture medium but also cause the purification of products more difficult.

Technologies and systems for biohydrogen production are well known, but currently imperfect for complex substrates. Most of the technical issues are related to the use of stand-alone technology, such as exclusive use of dark fermentation (Levin, 2004). The integrated biohydrogen and methane production system is currently the best solution to these issues. The advantages of the two-stage system include the efficiency of the process, higher yield of biogas and high total energy recovery (Hawkes et al., 2002). Figure 1 shows the emerging POME biohydrogen manufacturing approach using hybrid systems. In the first stage, POME will be transformed into organic acids and biohydrogen using dark fermentation, followed by the conversion of the organic acids into biohydrogen via photo fermentation. By implementing this hybrid system, biohydrogen production efficiency increased from the first stage at $50 \%$ to $70 \%$ in the second stage (Cheng et al., 2011). However, the main problem in the hybrid system is the implementation of the second stage

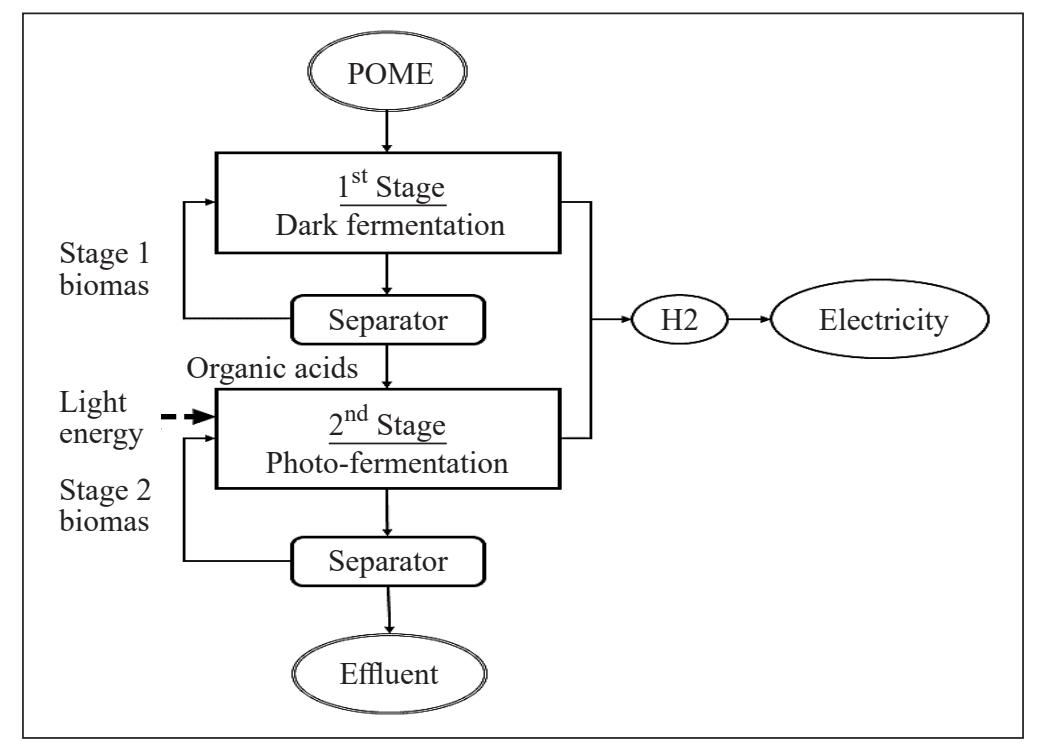

Figure 1. The proposed strategy of an integrated system by combining dark and photo fermentation to produce biohydrogen from POME as a carbon source 
(photo fermentation), where it requires high cost and complex infrastructure to set up the photobioreactor (Cheng et al., 2011).

Another method to improve the fermentation flux is through the integration of metabolic engineering of the microbial strains with optimal fermentation parameters. For example, integrating the metabolic engineering and low partial pressure during fermentation process was found to significantly enhance the hydrogen production (Mandal et al., 2006). However, not many kinds of research have been conducted in pairing metabolic engineering and bioprocessing technology. Most efforts in influencing the metabolic pathway of POME fermentation for biohydrogen production are centred on editing the Fe and Ni hydrogenases pathways as mentioned in another section.

The modification of existing pathways using metabolic engineering approaches will also lead to the creation of a new robust strain with higher hydrogen yield and better productivity. In addition, through metabolic engineering, genetic modification can be made to fully exploit the abundant substrate availability of POME and its derivatives (Taifor et al., 2017). These strategies can also be applied for other applications to construct recombinant strains to produce a wide range of chemicals and bioproducts. Therefore, the application of the metabolic engineering methods in industrial-scale bioprocessing is a promising study to improve the production of biohydrogen.

\section{CONCLUSION}

Dark fermentation is one of the anaerobic fermentation processes applied for biohydrogen production. The performance can be recovered by manipulating the factors that have tremendous influences on biohydrogen production, including $\mathrm{pH}$, temperature, medium formulation, and the application of genetic engineering. Bench studies provide basic essential information to know and understand the microbial limitation, environmental limitation, and operational condition for biohydrogen production. The production strains can be manipulated by genetic engineering to obtain the strains that can utilise POME for biohydrogen production with minimal intermediate products, such as organic acids, solvents, or amino acids. Another important step is to shift the biohydrogen production from bench to pilot scale-mostly operated by continuous systems, without compromising the ability of microorganisms to convert complex substrate into biohydrogen. Nevertheless, further investigation from the bench studies and the industry are needed to enhance the efficient utilisation of wastewater, like POME, towards maximal biohydrogen production through dark fermentation.

\section{ACKNOWLEDGEMENTS}

The authors would like to acknowledge and thank Universiti Putra Malaysia for the Grant Putra (UPM/700-2/1/GP-IPM/2017/9559800) and the provision of Graduate Research Fund to the first author, Fatin Sakinah Rosman. 


\section{REFERENCES}

Angenent, L. T., Karim, K., Al-Dahhan, M. H., Wrenn, B. A., \& Domiguez-Espinosa, R. (2004). Production of bioenergy and biochemicals from industrial and agricultural wastewater. Trends in Biotechnology, 22(9), 477-485. doi:10.1016/j.tibtech.2004.07.001

Burdette, D. S., Jung, S. H., Shen, G. J., Hollingsworth, R. I., \& Zeikus, J. G. (2002). Physiological function of alcohol dehydrogenases and long-chain (C30) fatty acids in alcohol tolerance of Thermoanaerobacter ethanolicus. Applied and Environmental Microbiology, 68(4), 1914-1918. doi:10.1128/aem.68.4.19141918.2002

Chaudhary, N., Ngadi, M. O., \& Simpson, B. (2012). Comparison of glucose, glycerol and crude glycerol fermentation by Escherichia Coli K12. Journal of Bioprocessing \& Biotechniques, S(01), 1-5. doi:10.4172/2155-9821.s1-001

Cheng, C. L., Lo, Y. C., Lee, K. S., Lee, D. J., Lin, C. Y., \& Chang, J. S. (2011). Biohydrogen production from lignocellulosic feedstock. Bioresource Technology, 102(18), 8514-8523. doi:10.1016/j. biortech.2011.04.059

Cheng, J., Su, H., Zhou, J., Song, W., \& Cen, K. (2011). Hydrogen production by mixed bacteria through dark and photo fermentation. International Journal of Hydrogen Energy, 36(1), 450-457. doi:10.1016/j. ijhydene.2010.10.007

Chin, H. L., Chen, Z. S., \& Chou, C. P. (2003). Fedbatch operation using Clostridium acetobutylicum suspension culture as biocatalyst for enhancing hydrogen production. Biotechnology Progress, 19(2), 383-388. doi:10.1021/bp0200604

Chong, M. L., Rahim, R. A., Shirai, Y., \& Hassan, M. A. (2009). Biohydrogen production by Clostridium butyricum EB6 from palm oil mill effluent. International Journal of Hydrogen Energy, 34(2), 764-771. doi:10.1016/j.ijhydene.2008.10.095

Chong, M. L., Sabaratnam, V., Shirai, Y., \& Hassan, M. A. (2009). Biohydrogen production from biomass and industrial wastes by dark fermentation. International Journal of Hydrogen Energy, 34(8), 3277-3287. doi:10.1016/j.ijhydene.2009.02.010

Chou, C. J., Jenney, F. E., Jr., Adams, M. W., \& Kelly, R. M. (2008). Hydrogenesis in hyperthermophilic microorganisms: Implications for biofuels. Metabolic Engineering, 10(6), 394-404. doi:10.1016/j. ymben.2008.06.007

Chou, C. J., Shockley, K. R., Conners, S. B., Lewis, D. L., Comfort, D. A., Adams, M. W., \& Kelly, R. M. (2007). Impact of substrate glycoside linkage and elemental sulfur on bioenergetics of and hydrogen production by the hyperthermophilic archaeon Pyrococcus furiosus. Applied and Environmental Microbiology, 73(21), 6842-6853. doi:10.1128/aem.00597-07

Fang, X., Sastry, A., Mih, N., Kim, D., Tan, J., Yurkovich, J. T., . . Palsson, B. O. (2017). Global transcriptional regulatory network for Escherichia coli robustly connects gene expression to transcription factor activities. Proceedings of the National Academy of Sciences, 114(38), 10286-10291. doi:10.1073/pnas.1702581114

Ferchichi, M., Crabbe, E., Hintz, W., Gil, G. H., \& Almadidy, A. (2005). Influence of culture parameters on biological hydrogen production by Clostridium saccharoperbutylacetonicum ATCC 27021. World Journal of Microbiology and Biotechnology, 21(6-7), 855-862. doi:10.1007/s11274-004-5972-0 
Forzi, L., \& Sawers, R. G. (2007). Maturation of [NiFe]-hydrogenases in Escherichia coli. BioMetals, 20(3-4), 565-578. doi:10.1007/s10534-006-9048-5

Georgieva, T. I., Skiadas, I. V., \& Ahring, B. K. (2007). Effect of temperature on ethanol tolerance of a thermophilic anaerobic ethanol producer Thermoanaerobacter A10: Modeling and simulation. Biotechnology and Bioengineering, 98(6), 1161-1170. doi:10.1002/bit.21536

Hallenbeck, P. C. (2005). Fundamentals of the fermentative production of hydrogen. Water Science Technology, 52(1-2), 21-29. doi:10.2166/wst.2005.0494

Hassan, M. A., Shirai, Y., Kusubayashi, N., Karim, M. I. A., Nakanishi, K., \& Hasimoto, K. (1997). The production of polyhydroxyalkanoate from anaerobically treated palm oil mill effluent by Rhodobacter sphaeroides. Journal of Fermentation and Bioengineering, 83(5), 485-488. doi:10.1016/s0922$338 x(97) 83007-3$

Hawkes, F., Hussy, I., Kyazze, G., Dinsdale, R., \& Hawkes, D. (2007). Continuous dark fermentative hydrogen production by mesophilic microflora: Principles and progress. International Journal of Hydrogen Energy, 32(2), 172-184. doi:10.1016/j.ijhydene.2006.08.014

Hawkes, F. R., Dinsdale, R., Hawkes, D. L., \& Hussy, I. (2002). Sustainable fermentative hydrogen production: Challenges for process optimisation. International Journal of Hydrogen Energy, 27(11-12), 1339-1347. doi:10.1016/s0360-3199(02)00090-3

Hipolito, C. N., Crabbe, E., Badillo, C. M., Zarrabal, O. C., Morales Mora, M. A., Flores, G. P., ... \& Ishizaki, A. (2008). Bioconversion of industrial wastewater from palm oil processing to butanol by Clostridium saccharoperbutylacetonicum N1-4 (ATCC 13564). Journal of Cleaner Production, 16(5), 632-638. doi:10.1016/j.jclepro.2007.02.005

Hwang, M. H., Jang, N. J., Hyun, S. H., \& Kim, I. S. (2004). Anaerobic bio-hydrogen production from ethanol fermentation: the role of pH. Journal of Biotechnology, 111(3), 297-309. doi:10.1016/j.jbiotec.2004.04.024

IEA. (2020). World energy prices 2020. International Energy Agency. Retrieved October 5, 2020, from https:// www.iea.org/reports/energy-prices-2020

Ismail, I., Hassan, M. A., Abdul Rahman, N. A., \& Soon, C. S. (2010). Thermophilic biohydrogen production from palm oil mill effluent (POME) using suspended mixed culture. Biomass and Bioenergy, 34(1), 4247. doi:10.1016/j.biombioe.2009.09.009

Kamal, S. A., Jahim, J. M., Anuar, N., Hassan, O., Daud, W. R. W., Mansor, M. F., \& Rashid, S. S. (2012). Pre-treatment effect of Palm Oil Mill Effluent (POME) during hydrogen production by a local isolate Clostridium butyricum. International Journal on Advanced Science, Engineering and Information Technology, 2(4), 325-331. doi:10.18517/ijaseit.2.4.214

Kapdan, I. K., \& Kargi, F. (2006). Bio-hydrogen production from waste materials. Enzyme and Microbial Technology, 38(5), 569-582. doi:10.1016/j.enzmictec.2005.09.015

Kim, S., Seol, E., Oh, Y. K., Wang, G. Y., \& Park, S. (2009). Hydrogen production and metabolic flux analysis of metabolically engineered Escherichia coli strains. International Journal of Hydrogen Energy, 34(17), 7417-7427. doi:10.1016/j.ijhydene.2009.05.053 
Kyazze, G., Martinez-Perez, N., Dinsdale, R., Premier, G. C., Hawkes, F. R., Guwy, A. J., \& Hawkes, D. L. (2006). Influence of substrate concentration on the stability and yield of continuous biohydrogen production. Biotechnology Bioengineering, 93(5), 971-979. doi:10.1002/bit.20802

Lee, D. H., Lee, D. J., \& Chiu, L. H. (2011). Biohydrogen development in United States and in China: An input-output model study. International Journal of Hydrogen Energy, 36(21), 14238-14244. doi:10.1016/j. ijhydene.2011.05.084

Levin, D. (2004). Biohydrogen production: Prospects and limitations to practical application. International Journal of Hydrogen Energy, 29(2), 173-185. doi:10.1016/s0360-3199(03)00094-6

Li, D., \& Chen, H. (2007). Biological hydrogen production from steam-exploded straw by simultaneous saccharification and fermentation. International Journal of Hydrogen Energy, 32(12), 1742-1748. doi:10.1016/j.ijhydene.2006.12.011

Lin, C. Y., \& Lay, C. H. (2004a). Carbon/nitrogen-ratio effect on fermentative hydrogen production by mixed microflora. International Journal of Hydrogen Energy, 29(1), 41-45. doi:10.1016/s0360-3199(03)00083-1

Lin, C. Y., \& Lay, C. H. (2004b). Effects of carbonate and phosphate concentrations on hydrogen production using anaerobic sewage sludge microflora. International Journal of Hydrogen Energy, 29(3), 275-281. doi:10.1016/j.ijhydene.2003.07.002

Lin, C., \& Lay, C. (2005). A nutrient formulation for fermentative hydrogen production using anaerobic sewage sludge microflora. International Journal of Hydrogen Energy, 30(3), 285-292. doi:10.1016/j. ijhydene.2004.03.002

Lin, Y. B., Chen, H., \& Yue, L. R. (2011). Effects of $\mathrm{K}_{2} \mathrm{HPO}_{4}$ on fermentative biohydrogen production of biohydrogenbacterium R3 Sp.nov. Advanced Materials Research, 280, 1-4. doi:10.4028/www.scientific. net/amr.280.1

Mandal, B., Nath, K., \& Das, D. (2006). Improvement of biohydrogen production under decreased partial pressure of H2 by Enterobacter cloacae. Biotechnology Letters, 28(11), 831-835. doi:10.1007/s10529006-9008-8

Mohd Yasin, N. H., Fukuzaki, M., Maeda, T., Miyazaki, T., Hakiman Che Maail, C. M., Ariffin, H., \& Wood, T. K. (2013). Biohydrogen production from oil palm frond juice and sewage sludge by a metabolically engineered Escherichia coli strain. International Journal of Hydrogen Energy, 38(25), 10277-10283. doi:10.1016/j.ijhydene.2013.06.065

Mohd Yasin, N. H., Rahman, N. A. A., Man, H. C., Mohd Yusoff, M. Z., \& Hassan, M. A. (2011). Microbial characterization of hydrogen-producing bacteria in fermented food waste at different $\mathrm{pH}$ values. International Journal of Hydrogen Energy, 36(16), 9571-9580. doi:10.1016/j.ijhydene.2011.05.048

Mokhtar, M., Mohd Yusoff, M. Z., Mohamad Ali, M. S., Mustapha, N. A., Wood, T. K., \& Maeda, T. (2019). Pseudogene YdfW in Escherichia Coli decreases hydrogen production through nitrate respiration pathways. International Journal of Hydrogen Energy, 44(31), 16212-16223. doi:10.1016/j.ijhydene.2019.04.228

Morimoto, K., Kimura, T., Sakka, K., \& Ohmiya, K. (2005). Overexpression of a hydrogenase gene in Clostridium paraputrificum to enhance hydrogen gas production. FEMS Microbiology Letters, 246(2), 229-234. doi:10.1016/j.femsle.2005.04.014 
Mumtaz, T., Abd-Aziz, S., Rahman, A. A., Yee, P. L., \& Hassan, M. A. (2008). Pilot-scale recovery of low molecular weight organic acids from anaerobically treated palm oil mill effluent (POME) with energy integrated system. African Journal of Biotechnology, 7, 3900-3905. doi:10.5897/AJB08.640

Najafpour, G. D., Shahavi, M. H., \& Neshat, S. A. (2015). Assessment of biological hydrogen production processes: A review. In International Conference on Chemical and Bioprocess Engineering (pp. 1-10). Kota Kinabalu, Malaysia. doi:10.3303/CET1865042

O-thong, S., Mamimin, C., \& Prasertsan, P. (2011). Effect of temperature and initial pH on biohydrogen production from palm oil mill effluent: Long-term evaluation and microbial community analysis. Electronic Journal of Biotechnology, 14(5), 1-12. doi:10.2225/vol14-issue5-fulltext-9

O-Thong, S., Prasertsan, P., Intrasungkha, N., Dhamwichukorn, S., \& Birkeland, N. K. (2007). Improvement of biohydrogen production and treatment efficiency on palm oil mill effluent with nutrient supplementation at thermophilic condition using an anaerobic sequencing batch reactor. Enzyme and Microbial Technology, 41(5), 583-590. doi:10.1016/j.enzmictec.2007.05.002

Prasertsan, P., O-Thong, S., \& Birkeland, N. K. (2009). Optimization and microbial community analysis for production of biohydrogen from palm oil mill effluent by thermophilic fermentative process. International Journal of Hydrogen Energy, 34(17), 7448-7459. doi:10.1016/j.ijhydene.2009.04.075

Rani, K. S., \& Seenayya, G. (1999). High ethanol tolerance of new isolates of Clostridium thermocellum strains SS21 and SS22. World Journal of Microbiology and Biotechnology, 15(2), 173-178. doi:10.1023/A:1008863410460

Rasdi, Z., Nor`Aini, A. R., Abd-Aziz, S., Phang, L.=Y., Mohd Yusoff, M. Z., Chong, M. L., \& Hassan, M. A. (2009). Statistical optimization of biohydrogen production from palm oil mill effluent by natural microflora. The Open Biotechnology Journal, 3(1), 79-86. doi:10.2174/1874070700903010079

Saady, N. M. C. (2013). Homoacetogenesis during hydrogen production by mixed cultures dark fermentation: Unresolved challenge. International Journal of Hydrogen Energy, 38(30), 13172-13191. doi:10.1016/j. ijhydene.2013.07.122

Sanchez-Torres, V., Mohd Yusoff, M. Z., Nakano, C., Maeda, T., Ogawa, H. I., \& Wood, T. K. (2013). Influence of Escherichia coli hydrogenases on hydrogen fermentation from glycerol. International Journal of Hydrogen Energy, 38(10), 3905-3912. doi:10.1016/j.ijhydene.2013.01.031

Singh, R. P., Ibrahim, M. H., Esa, N., \& Iliyana, M. S. (2010). Composting of waste from palm oil mill: A sustainable waste management practice. Reviews in Environmental Science and Bio/Technology, 9(4), 331-344. doi:10.1007/s11157-010-9199-2

Taifor, A. F., Zakaria, M. R., Mohd Yusoff, M. Z., Toshinari, M., Hassan, M. A., \& Shirai, Y. (2017). Elucidating substrate utilization in biohydrogen production from palm oil mill effluent by Escherichia coli. International Journal of Hydrogen Energy, 42(9), 5812-5819. doi:10.1016/j.ijhydene.2016.11.188

US Department of Energy (2020). Clean cities alternative fuel price report. Retrieved October 5, 2020, from https://afdc.energy.gov/fuels/prices.html

Van Ginkel, S., \& Logan, B. E. (2005). Inhibition of biohydrogen production by undissociated acetic and butyric acids. Environmental Science \& Technology, 39(23), 9351-9356. doi:10.1021/es0510515 
Vignais, P., Magnin, J., \& Willison, J. (2006). Increasing biohydrogen production by metabolic engineering. International Journal of Hydrogen Energy, 31(11), 1478-1483. doi:10.1016/j.ijhydene.2006.06.013

Vignais, P. M., \& Billoud, B. (2007). Occurrence, classification, and biological function of hydrogenases: An overview. Chemical Reviews 107(10), 4206-4272. doi:10.1021/cr050196r

Xu, Q., Singh, A., \& Himmel, M. E. (2009). Perspectives and new directions for the production of bioethanol using consolidated bioprocessing of lignocellulose. Current Opinion in Biotechnology, 20(3), 364-371. doi:10.1016/j.copbio.2009.05.006

Yang, H., \& Shen, J. (2006). Effect of ferrous iron concentration on anaerobic bio-hydrogen production from soluble starch. International Journal of Hydrogen Energy, 31(15), 2137-2146. doi:10.1016/j. ijhydene.2006.02.009

Yossan, S., O-Thong, S., \& Prasertsan, P. (2012). Effect of initial pH, nutrients and temperature on hydrogen production from palm oil mill effluent using thermotolerant consortia and corresponding microbial communities. International Journal of Hydrogen Energy, 37(18), 13806-13814. doi:10.1016/j. ijhydene.2012.03.151

Yusoff, M. Z. M., Hassan, M. A., Abd-Aziz, S., \& Nor Aini, A. R. (2009). Start-up of biohydrogen production from palm oil mill effluent under non-sterile condition in $50 \mathrm{~L}$ continuous stirred tank reactor. International Journal of Agricultural Research, 4(4), 163-168. doi:10.3923/ijar.2009.163.168 